\title{
EVALUATION OF POD SHATTERING RESISTANCE AND AGRONOMIC PERFORMANCE OF SEVERAL SOYBEAN PROMISING LINES
}

\author{
[Evaluasi Ketahanan Pecah Polong dan Keragaan Karakter Agronomi Beberapa Galur \\ Harapan Kedelai]
}

\author{
Ayda Krisnawati ${ }^{1 *}$, M. Muchlish Adie ${ }^{1}$, and Dotti Suryati ${ }^{2}$ \\ ${ }^{1}$ Indonesian Legume and Tuber Crops Research Institute (ILETRI) \\ Jl Raya Kendalpayak KM 8, Malang, Indonesia \\ ${ }^{2}$ University of Bengkulu, Bengkulu, Indonesia \\ email: aydakrisnawati@pertanian.go.id
}

\begin{abstract}
Kehilangan hasil karena pecah polong merupakan masalah budidaya kedelai di Indonesia.Tujuan penelitian adalah untuk mengevaluasi ketahanan beberapa genotipe kedelai terhadap pecah polong dan keragaan karakter agronominya. Penelitian lapang dilaksanakan di lahan kering di Lampung Selatan dari bulan Mei - Agustus 2017 dengan menggunakan rancangan acak kelompok dengan 12 genotipe kedelai sebagai perlakuan dan jumlah ulangan adalah empat kali. Pemetaan ketahanan terhadap pecah polong menggunakan metode oven dan penjemuran brangkasan di bawah sinar matahari. Pada metode oven, pada saat polong telah masak, diambil 30 polong untuk setiap genotipe di oven pada suhu $30{ }^{\circ} \mathrm{C}$ selama 3 hari, $40{ }^{\circ} \mathrm{C}$ selama 1 hari, $50{ }^{\circ} \mathrm{C}$ selama 1 hari, dan pada suhu $60{ }^{\circ} \mathrm{C}$ selama 1 hari. Pada metode penjemuran di bawah sinar matahari, setiap perlakuan diambil 10 tanaman dan brangkasan dijemur di bawah sinar matahari. Rata-rata pecah polong pada suhu $30^{\circ} \mathrm{C}, 40^{\circ} \mathrm{C}, 50^{\circ} \mathrm{C}$ dan $60^{\circ} \mathrm{C}$ masing-masing adalah $0,8.26,46.13$, dan $51.06 \%$. Rentang pecah polong pada suhu $60^{\circ} \mathrm{C}$ antara 3.62 - 87.23\%. Pada metode penjemuran di bawah sinar matahari setelah hari ke 15 , rentang pecah polong antara 0 - 67.36\%.Pada metode oven berhasil teridentifikasi 2 genotipe tergolong tahan (Anjasmoro dan G511H/Anj-1-3) dan pada metode penjemuran di bawah sinar matahari diperoleh 3 genotipe tergolong tahan pecah polong (Anjasmoro, G511H/Anj-1-3, G 511 H/Anjasmoro1-4).Evaluasi ketahanan pecah polong dengan metode oven memberikan tekanan yang lebih berat dibandingkan dengan metode penjemuran di bawah sinar matahari.Anjasmoro dan G511H/Anj-1-3 konsisten tahan pada kedua metode pemetaan ketahanan terhadap pecah polong.Genotipe G511H/Anj-1-3 berdaya hasil tinggi (3.27 t/ha), ukuran biji besar, dan berumur genjah, sehingga sesuai dikembangkan di daerah tropis Indonesia. Ketersediaan varietas kedelai yang berdaya hasil tinggi dan tahan pecah polong akan bermanfaat dalam meningkatkan produktivitas kedelai.
\end{abstract}

Keyword: karakter agronomi, kedelai, metode oven, metode penjemuran sinar matahari, pecah polong

\section{ABSTRACT}

Pod shattering is one of the sources of yield losses during soybean cultivation in Indonesia. This research aimed to identify the resistant genotypes to pod shattering and the performance of its agronomic characters. The field study was conducted in the dry land of South Lampung from May to August 2017 using twelve soybean genotypes. The experiment was arranged in a randomized block design with four replicates. The observation of pod shattering was using oven-dry and sun-drying methods. The result showed that a rise temperature of oven increased the pod shattering. The rates of shattering on oven temperature of $30^{\circ} \mathrm{C}, 40^{\circ} \mathrm{C}, 50{ }^{\circ} \mathrm{C}$, and $60^{\circ} \mathrm{C}$ were of 0 , $8.26 \%, 46.13 \%$, and $51.06 \%$, respectively. The rate of shattering of oven-dry method at $60{ }^{\circ} \mathrm{C}$ ranged from $3.62-87.23 \%$. On the sun-drying method, the rate of shattering after 15 days treatment was ranged from $0-67.36 \%$. The screening for pod shattering by using the oven-dry method has successfully obtained two resistant varieties to pod shattering (Anjasmoro and G511H/Anj-1-3), whereas by using the sun-drying method there were three resistant genotypes (Anjasmoro, G511H/Anj-1-3, G511H/Anjasmoro-1-4). The evaluation of shattering resistance using oven-dry method resulted in a higher pressure than those of by sun-drying method. The Anjasmoro variety and G511H/Anj1-3 showed consistent resistance to pod shattering by both methods. The G511H/Anj-1-3produced high yield, have large seed size and early days ofmaturity. Thus, the G511H/Anj-1-3was potentially be developed in Indonesiaand other tropical regions. The availability of a high yield and shattering resistant genotype will be beneficial to increase soybean productivity.

Keyword: agronomic characters, oven-dry, pod shattering, sun-drying, soybean

\section{INTRODUCTION}

Yield loss is one of the problems during the improvement of food crop production, including in soybean commodity. One of the causes of yield losses in soybeans is the occurrence of pod shattering. The soybean yield losses due to pod shattering may be reached $100 \%$, depending on the susceptibility of the soybean varieties used, the growing season, and the duration of harvest delays. In Indonesia, most of the soybeans are cultivated during the dry season, thus the days to maturity is during the peak of the dry season. This condition (high temperature and low humidity) will increase the occurrence of pod shattering (Tukamuhabwa et al. 2002; Bara et al. 2013). Furthermore, the development of soybeans outside the Java Island will be faced with the scarcity of labor thus will cause delays in the soybean harvest and spur the pod shattering occurrence.

Pod shattering is the opening of mature pod 
along the dorsal or ventral sutures and followed by seed dispersal when the crop reaches maturity and during harvesting (Bara et al., 2013). Prevention of the yield losses caused by pod shattering is different due to biotic (pest and disease) or abiotic (such as drought) stresses, which can be solved by pest and disease control or irrigation. The effective way to reduce the pod shattering is by using a resistant variety. The morphological architecture of the plant, anatomical structures of the pod, chemical composition of the pod wall, genetic constitution of the variety and environmental conditions at maturity determine the degree of pod shattering (Gulluoglu et al., 2006).

Development of resistant variety requires genetic variability, and it has been reported that soybean resistance to pod shattering was controlled by two genes and was partially dominant over resistance (Tukamuhabwa et al., 2000). Soybean resistance to pod shattering is associated with various pod morphology. Adeyeye et al. (2014) reported that pod diameter was negatively correlated with pod shattering. Soybean genotype with a small pod, less width and low volume/weight of seed was tolerant to pod shattering (Bara et al., 2013). Soybean resistance to pod shattering is also determined by pod attributes, such as angles, length, and width, and plant architecture such as plant height and stem stiffness (Thompson and Hughes, 1986). Agrawal et al. (2002) revealed that the activity of cellulose enzyme was shifted from the nonshattering zone to the shattering zone in susceptible variety and vice versa in resistant variety. On the Brassica napus plant, it was reported that pod shattering resistance was positively correlated with pod wall weight, but it was not correlated with pod density, pod length and width, or seed number per pod (Morgan et al., 1998). A molecular study on pod shattering has already begun, such as by Funatsuki et al. (2014) which found that the gene for the shattering-resistant genotype, $p d h 1$, was defective and with a premature stop codon.

Pod shattering on soybean has become a serious problem in soybean production centers, both in tropical and subtropical regions. Various environmental factors that caused pod shattering were low humidity, high temperature, and rapid temperature changes, and dry weather followed rains at harvesting (Mohammed, 2010; Kuai et al., 2016; Liu et al., 2016). A screening for pod shattering resistance on 150 soybean genotypes derived from crossing by Krisnawati and Adie (2017a) obtained several resistant genotypes. Adeyeye et al. (2014) performed screening for pod resistance in the field and pot, and they obtained the rate of shattering from $0.8-8.6 \%$ and $0.7-3.7 \%$, respectively. Research by Antwi-Boasiako (2017) found six genotypes with moderately resistant to pod shattering, namely SIT-M TGx1904-6F, SIT-E TGx1835-10E, SIT-M TGx1987-40F, TGx1903-7F, SIT-E TGx1448-2E and Anidaso. The opportunity to obtain soybean resistant to pod shattering is having a high chance of success. However, the development of soybean improved variety is not only resistant to pod shattering but also must have high economic value and conform to the requirement of industrial raw material. Thus, it will be beneficial to society in terms of increasing productivity and also in accordance with the consumer's preference.

The aims of the research were to identify the resistant genotypes to pod shattering and the performance of its agronomic characters.

\section{MATERIALS AND METHODS}

\section{Field study}

The field research was conducted in dry land of Banjarnegeri Village, District of Natar, Lampung Selatan Regency, from May to September 2017. The research material comprising 10 soybean promising lines and two check varieties, i.e. Anjasmoro (resistant to pod shattering, large seed size) and Demas 1 (adaptive to dry acid soil). The experiment was arranged in a randomized block design with 12 treatments and each treatment was replicated four times. The drainage channel was made as needed. The plot size was $2.0 \times 4.5 \mathrm{~m}$, plant spacing of $40 \mathrm{~cm}$ x $15 \mathrm{~cm}$, two seeds per hill. The fertilizer was applied entirely at planting which consisted of $250 \mathrm{~kg}$ Phonska/ha, $100 \mathrm{~kg}$ SP 36, and $1 \mathrm{t} / \mathrm{ha}$ organic fertilizer. The weed controls were done before planting, two weeks after planting, and four weeks after planting. The pest and disease were optimally controlled. Harvesting was done when $90 \%$ of pods have reached maturity (R8). Agronomic characters 
were observed on plant height, number of branches, number of nodes, number of filled pods, and seed yield.

\section{Resistance to pod shattering}

Resistance evaluation of 12 soybean genotypes to pod shattering was using two methods, i.e. oven-dry method and sun-drying method. On the oven-dry method, when the soybean plant has fully mature (R8), a total of 30 pods were randomly taken from each plot. Pods were placed on petridish and then kept in an oven. The oven was set into $30{ }^{\circ} \mathrm{C}$ for three days, and then elevated up to $40{ }^{\circ} \mathrm{C}$ for one day, elevated up to $50{ }^{\circ} \mathrm{C}$ for one day, and elevated up to $60{ }^{\circ} \mathrm{C}$ for one day. Observation for pod shattering was made (Krisnawati and Adie, 2017a). The evaluation for pod shattering using the sundrying method was done by randomly taken three sample plants at R8. Then plants were dried under the sun for 15 days. Observation for pod shattering was made every day. The evaluation of shattering resistance was following a method by Mohammed (2010) as follows: resistant (0-10\% shattered pods), moderate ( $11-70 \%$ shattered pods), and susceptible $(71-100 \%$ shattered pods $)$.

\section{Data analysis}

The data of agronomic characters were analyzed using a randomized block analysis of variance (ANOVA) to determine the effect of treatment (genotype), and continued with the LSD test at 5\% $(\mathrm{p}<0.05)$ and $1 \%(\mathrm{p}<0.01)$ probability level.

\section{RESULT}

Pod shattering resistance by using oven-dry method

The screening of soybean genotypes to pod shattering using the oven-dry method (Table 1, Figure 1) showed that increasing oven temperature caused a higher pod shattering. The temperature of $30^{\circ} \mathrm{C}$ was not affect the occurrence of pod shattering. The average of shattering was $8.26 \%$ at $40{ }^{\circ} \mathrm{C}$, and increased to $46.53 \%$ at $50^{\circ} \mathrm{C}$, and then reached $51.06 \%$ at $60{ }^{\circ} \mathrm{C}$. The oven temperature between $30{ }^{\circ} \mathrm{C}$ and $40{ }^{\circ} \mathrm{C}$ was more influenced on the decrease of pod water content. There was variability in pod shattering resistance among 12 soybean genotypes at temperature of $50{ }^{\circ} \mathrm{C}$ and $60{ }^{\circ} \mathrm{C}$.

Pod shattering at $50{ }^{\circ} \mathrm{C}$ ranged from $0.56-87.23 \%$, and there were two resistant genotypes. Increasing the oven temperature to $60{ }^{\circ} \mathrm{C}$ showed variability of pod shattering from $3.62-87.23 \%$, or there were two resistant genotypes, five moderately resistant, and five susceptible genotypes to pod shattering.

\section{Pod shattering resistance by using sun-drying method}

The screening of soybean genotypes to pod shattering using the sun-drying method until 15 days was presented in Table 2. The duration of sun-drying was parallel with the increase of pod shattering (Figure 2). The sun-drying up to eight days showed the average of shattering $12.86 \%$, and increased to $26.88 \%$ on the $15^{\text {th }}$ days. This indicates that most of

Table 1. Soybean resistance to pod shattering by oven-dry method (Ketahanan kedelai terhadap pecah polong berdasarkan metode oven)

\begin{tabular}{clcccc}
\hline No & Genotype (Genotipe) & \multicolumn{3}{c}{ Pod shattering (\%) [Pecah polong (\%)] } \\
\cline { 3 - 6 } & & $30^{\circ} \mathrm{C}$ & $40^{\circ} \mathrm{C}$ & $50^{\circ} \mathrm{C}$ & $60^{\circ} \mathrm{C}$ \\
\hline 1 & $11 \mathrm{AB}$ & 0 & 18.61 & 74.99 & 79.43 \\
2 & $13 \mathrm{ED}$ & 0 & 16.66 & 80.55 & 81.11 \\
3 & 14 DD & 0 & 12.23 & 87.23 & 87.23 \\
4 & $19 \mathrm{BE}$ & 0 & 13.33 & 83.61 & 84.44 \\
5 & 25 EC & 0 & 8.61 & 49.17 & 50.83 \\
6 & G511H/Kaba//Kaba///Kaba-8-6 & 0 & 3.61 & 13.05 & 16.66 \\
7 & G511H/Anjs//Anjs-2-10 & 0 & 7.22 & 46.38 & 63.88 \\
8 & G511H/Anjs-1-3 & 0 & 0.00 & 1.39 & 6.67 \\
9 & G511H/Anj//Anj///Anj-11-2 & 0 & 4.44 & 31.67 & 39.73 \\
10 & G511H/Arg//Arg-2-1 & 0 & 12.50 & 74.44 & 82.23 \\
11 & Demas 1 & 0 & 1.94 & 15.28 & 16.94 \\
12 & Anjasmoro & 0 & 0 & 0.56 & 3.62 \\
\hline \multicolumn{7}{c}{ Average (Rata-rata) } & 0 & 8.26 & 46.53 & 51.06 \\
\hline
\end{tabular}






Figure 1. Soybean pod shattering at three different levels of temperature based on oven-dry method. The genotype numbers refer to Table 1 (Pecah polong kedelai pada tiga level suhu berdasar metode oven. Kode genotipe mengacu pada Tabel 1)

tested genotypes were only able to hold seeds until eight days of sun-drying, or only able to postpone the harvest for eight days because the average of shattering on the $9^{\text {th }}$ days has reached $12.86 \%$ (moderately resistant).

The sun-drying for seven days showed there were three moderately resistant genotypes. In the sun-drying up to 15 days, there were three resistant genotypes and nine others were moderately resistant.

\section{Identification of resistance to pod shattering}

Screening of resistance to pod shattering using oven-dry method will resulted a heavier pressure than the sun-drying method. The average of shattering by oven-dry method at $60{ }^{\circ} \mathrm{C}$ was $51.06 \%$, but by sun-drying method up to 15 days was $26.88 \%$ (Table 3, Figure 3).

Varying method of resistance identification has caused different degree of pressure on pod, hence resulted in different resistant group on each method. Soybean genotypes which categorized as susceptible and moderate by oven-dry method, all were categorized as moderate according to sun-drying method. However, there were two resistant genotypes according to both of oven-dry and sun-drying method, i.e. G511H/Anjs-1-3 and Anjasmoro variety. Thus, those two genotypes are categorized as resistant to pod shattering.

\section{Agronomic characters}

Users' preferences for soybean varieties in Indonesia are high yield, resistant to pod shattering, and has suitable agronomic characteristics with tropical climate of Indonesia. Analysis of variance on characters of days to maturity, plant height, number of filled pod, 100 seed weight, and seed yield showed that genotype has significant effect for all those characters (Table 4), indicating the difference in tested soybean genotypes. The coefficient of variation $(\mathrm{CV})$ value ranged from 1.90 to $39.66 \%$.

The days to maturity of 12 soybean genotypes ranged from 75 - 85 days (average of 80 days), plant height ranged from $63.08-74.23 \mathrm{~cm}$ (average of $70.43 \mathrm{~cm}$ ), number of filled pod was between 76.67 to 113.08 pods/plant (average of 96.83 pods/plant), 100 seed weight ranged from $11.10-16.80 \mathrm{~g}$ (average of $14.39 \mathrm{~g}$ ), and seed yield was between 2.19 to $3.27 \mathrm{t} / \mathrm{ha}$ (average of $2.71 \mathrm{t} / \mathrm{ha}$ ) (Table 5).

Variety of Demas 1 has the longest duration of days to maturity ( 85 days). There were five genotypes with early days to maturity (between 75 - 77 days). The days to maturity of Anjasmoro reached 83 days (medium maturity). Plant height and number of filled pod were categorized as optimal for all genotypes. The seed size vary from 


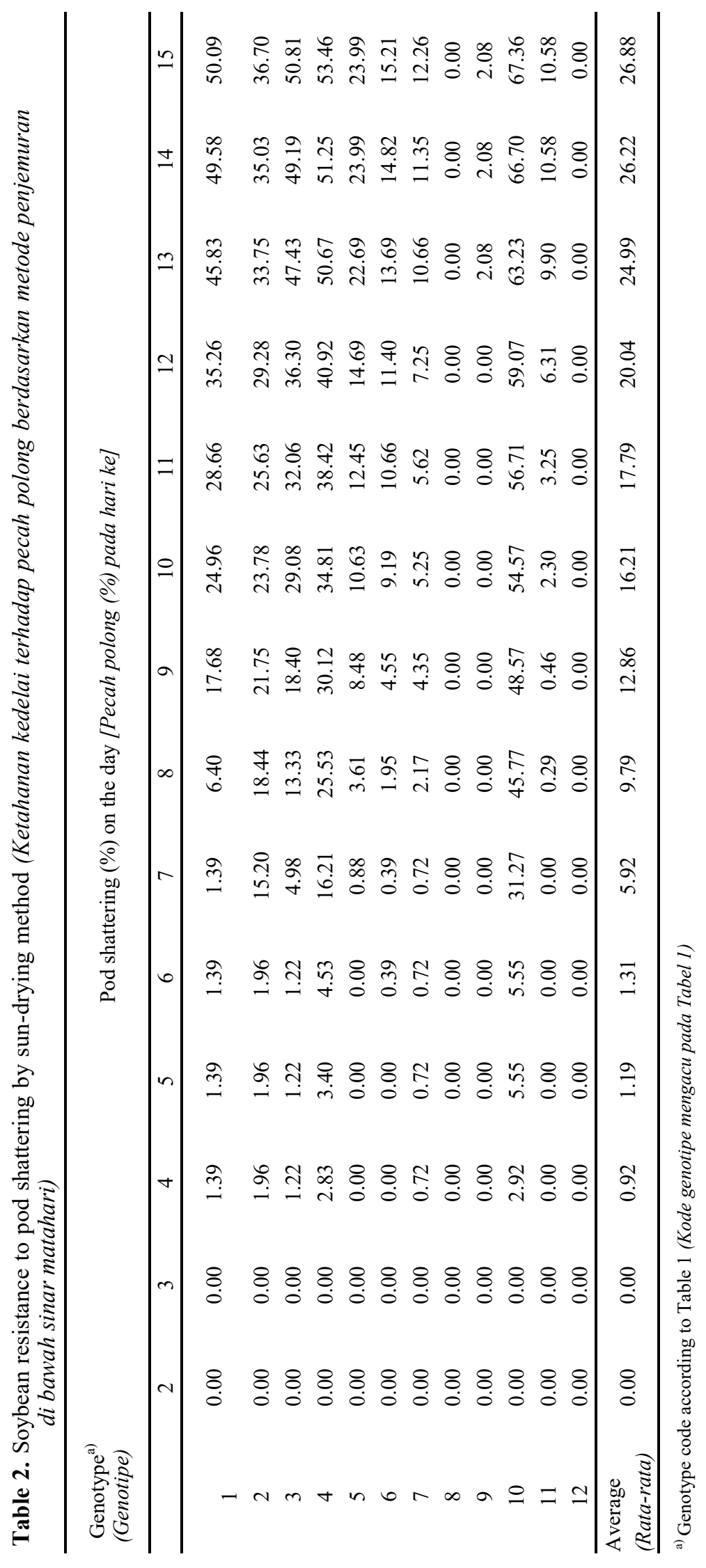




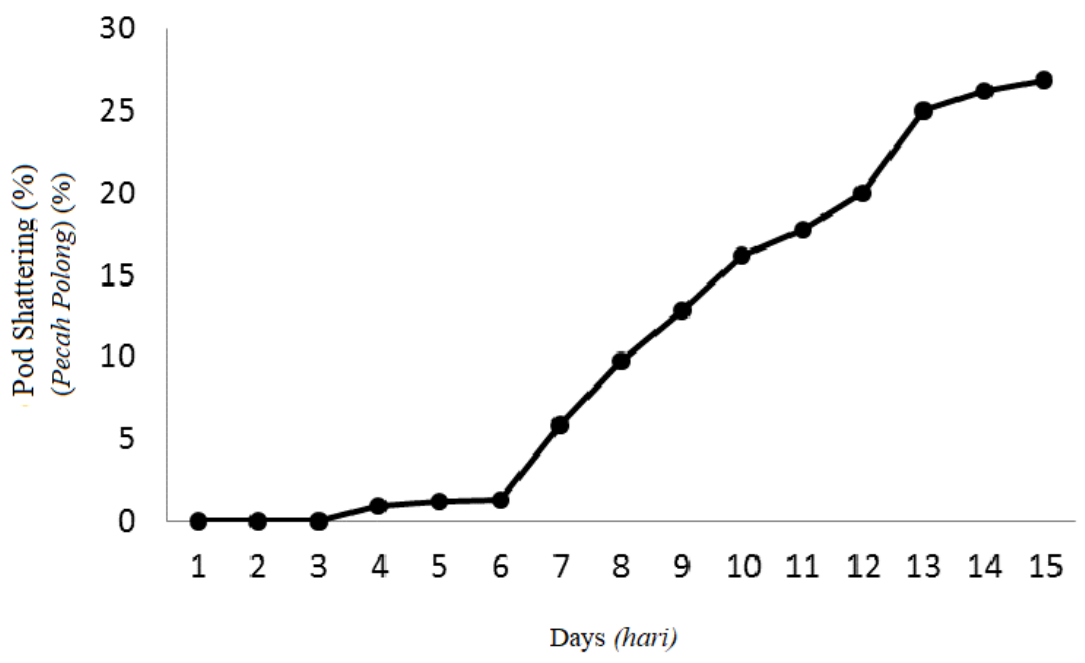

Figure 2. Average of soybean pod shattering for 15 days based on sun-drying method (Rata-rata pecah polong pada kedelai selama 15 hari berdasarkan metode penjemuran di bawah sinar matahari)

Table 3. Identification of resistance to pod shattering (Identifikasi ketahanan terhadap pecah polong)

\begin{tabular}{|c|c|c|c|c|c|}
\hline \multirow[t]{3}{*}{ No } & \multirow[t]{3}{*}{ Genotype (Genotipe) } & \multicolumn{4}{|c|}{ Pod shattering (\%) [Pecah polong (\%)] } \\
\hline & & \multicolumn{2}{|c|}{$\begin{array}{l}\text { Oven-dry method } \\
\text { (metode oven) }\end{array}$} & \multicolumn{2}{|c|}{$\begin{array}{l}\text { Sun-drying method (metode } \\
\text { penjemuran di bawah sinar } \\
\text { matahari) }\end{array}$} \\
\hline & & $60^{\circ} \mathrm{C}$ & Criteria & 15 days & Criteria \\
\hline 1 & $11 \mathrm{AB}$ & 79.43 & $\mathrm{~S}$ & 50.09 & MR \\
\hline 2 & $13 \mathrm{ED}$ & 81.11 & $\mathrm{~S}$ & 36.70 & MR \\
\hline 3 & $14 \mathrm{DD}$ & 87.23 & $\mathrm{~S}$ & 50.81 & MR \\
\hline 4 & $19 \mathrm{BE}$ & 84.44 & $\mathrm{~S}$ & 53.46 & MR \\
\hline 5 & $25 \mathrm{EC}$ & 50.83 & MR & 23.99 & MR \\
\hline 6 & $\mathrm{G} 511 \mathrm{H} / \mathrm{Kaba} / / \mathrm{Kaba} / / / \mathrm{Kaba}-8-6$ & 16.66 & MR & 15.21 & MR \\
\hline 7 & G511H/Anjs//Anjs-2-10 & 63.88 & MR & 12.26 & MR \\
\hline 8 & G511H/Anjs-1-3 & 6.67 & $\mathrm{R}$ & 0.00 & $\mathrm{R}$ \\
\hline 9 & G511H/Anj//Anj///Anj-11-2 & 39.73 & MR & 2.08 & $\mathrm{R}$ \\
\hline 10 & G511H/Arg//Arg-2-1 & 82.23 & $\mathrm{~S}$ & 67.36 & MR \\
\hline 11 & Demas 1 & 16.94 & MR & 10.58 & MR \\
\hline 12 & Anjasmoro & 3.62 & $\mathrm{R}$ & 0.00 & $\mathrm{R}$ \\
\hline & Average (Rata-rata) & 51.06 & & 26.88 & \\
\hline
\end{tabular}


Artikel Penelitian

Krisnawati et al. - Evaluation of Pod Shattering Resistance and Agronomic Performance

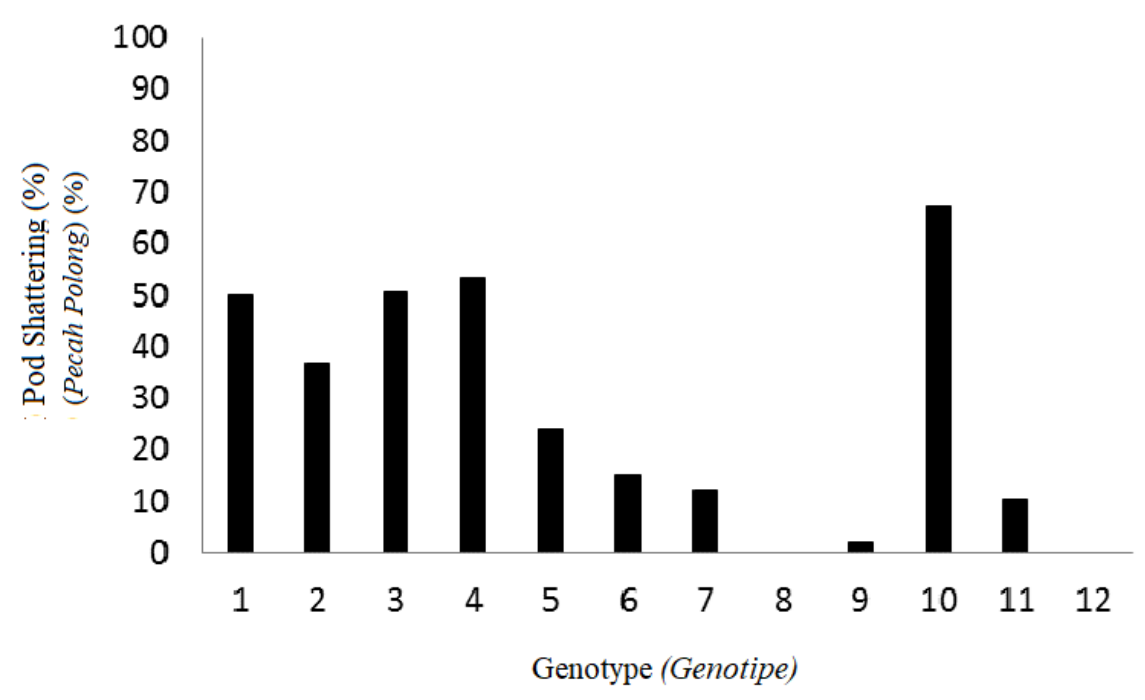

Figure 3. Soybean resistance to pod shattering of 12 genotypes at $15^{\text {th }}$ day (sun-drying method). (Genotype code according to Table 1) [Ketahanan 12 genotipe kedelai terhadap pecah polong pada hari ke-15 (metode penjemuran di bawah sinar matahari). Kode genotipe mengacu pada Tabel 1]
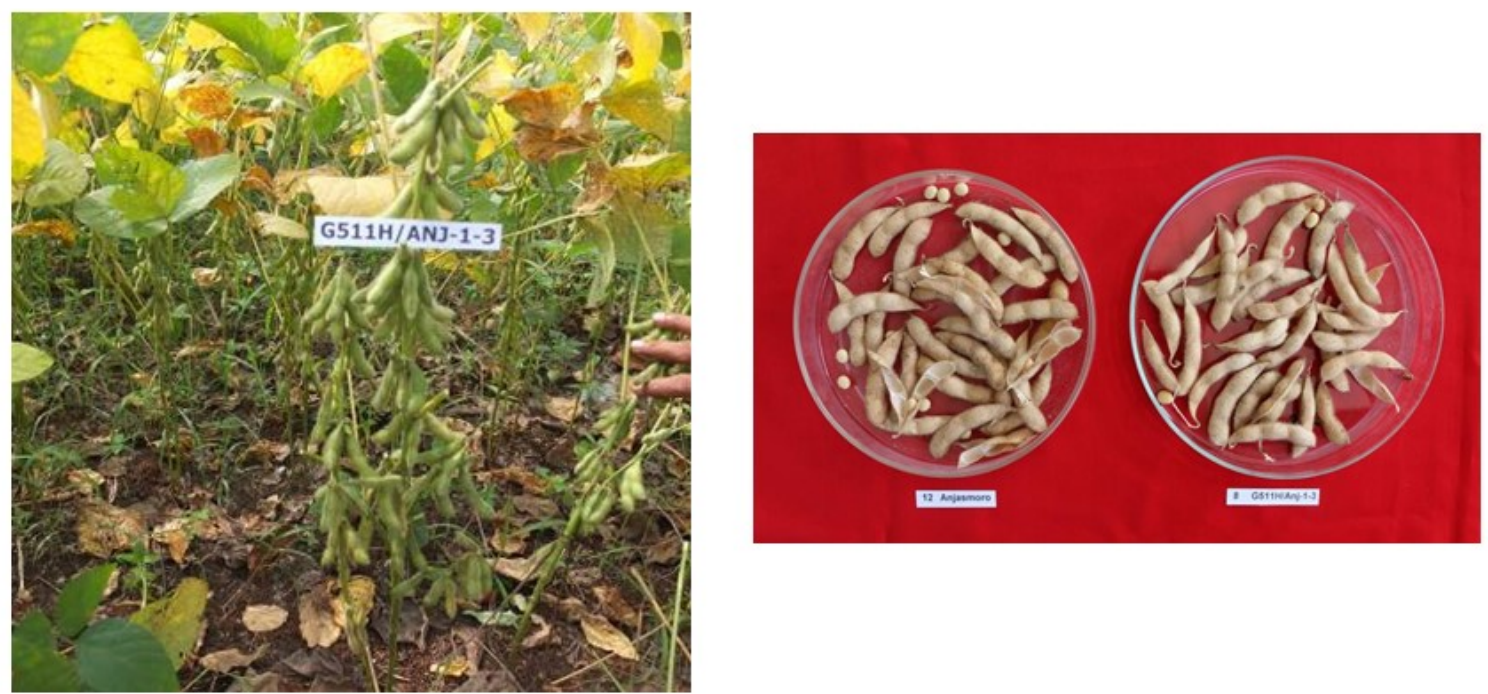

Figure 4. The performance of agronomic character and pod shattering resistance of G511H/Anjs-1-3 (Keragaan karakter agronomi dan ketahanan pecah polong dari genotipe G511H/Anjs-1-3) 
medium (five genotypes) to large (seven genotypes).

Optimum plant height and number of pods have an effect on the optimal seed yield. Moreover, there were two genotypes which able to produce over $3.0 \mathrm{t} / \mathrm{ha}$, namely $19 \mathrm{BE}(3.12 \mathrm{t} / \mathrm{ha})$ and G511H/ Anjs-1-3 (3.27 t/ha). Interestingly, genotype of G511H/Anjs-1-3 in addition have high yield was also resistant to pod shattering. However, $19 \mathrm{BE}$ was categorized as susceptible to pod shattering.

\section{DISCUSSION}

Indonesia is one of the largest soybean consumer in the world. Domestic soybean demand continues to increase as a result of increasing population consuming processed soybean. Efforts to increase soybean productivity per unit area, followed by safeguarding soybean production in the field, are important steps to optimize the domestic soybean production.
In this study, the resistance to pod shattering vary among soybean genotypes. Pod shattering is one of problem of yield losses, especially in tropical region of Indonesia. Harvest delay due to labor scarcity and tropical environment condition triggering pod shattering on soybean (Krisnawati and Adie, 2017b). The most sensitive growth phase of soybean to pod shattering is R8 (full maturity, $90 \%$ of pods on the plant are mature). Screening of resistance using the oven-dry as well as the sun-drying method was able to identify several soybean genotypes to pod shattering. According to Agrawal et al. (2002), the pod shattering in the field was affected by several environmental factors, such as dry weather, low humidity, high temperature, and rapid temperature changes.

On the oven-dry method, the using of oven temperature of $30{ }^{\circ} \mathrm{C}$ and $40{ }^{\circ} \mathrm{C}$ were intended to reduce the pod moisture content. At $50{ }^{\circ} \mathrm{C}$, the range of shattered pods was $0.56 \%$ (Anjasmoro

Table 4. Analysis of variance for yield and yield components of 12 soybean genotypes (Sidik ragam hasil dan komponen hasil 12 genotipe kedelai)

\begin{tabular}{|c|c|c|c|c|}
\hline \multirow[b]{2}{*}{ No } & \multirow[b]{2}{*}{ Characters (Karakter) } & \multicolumn{2}{|c|}{ Mean square (Kuadrat tengah) } & \multirow[b]{2}{*}{$\mathrm{CV}(\%)$} \\
\hline & & $\begin{array}{c}\text { Replication } \\
\text { (Ulangan) }\end{array}$ & $\begin{array}{l}\text { Genotype } \\
\text { (Genotipe) }\end{array}$ & \\
\hline 1 & Days to maturity (days) & $3.4097^{\mathrm{ns}}$ & $49.3390^{* *}$ & 1.90 \\
\hline 2 & Plant height $(\mathrm{cm})$ & $42.8877^{\mathrm{ns}}$ & $273.7803^{* *}$ & 10.87 \\
\hline 3 & Number of filled pod/plant & $1563.2387^{*}$ & $446.5514^{\mathrm{ns}}$ & 22.07 \\
\hline 4 & 100 seed weight $(\mathrm{g})$ & $7.1966^{\mathrm{ns}}$ & $8.2501^{*}$ & 39.66 \\
\hline 5 & Seed yield $(\mathrm{t} / \mathrm{ha})$ & $0.7917^{* *}$ & $0.3597^{*}$ & 14.32 \\
\hline
\end{tabular}

$* *=$ significant at $1 \%$ probability level $(\mathrm{p}<0.01),{ }^{*}=$ significant at $5 \%$ probability level $(\mathrm{p}<0.05), \mathrm{ns}=$ not significant; $\mathrm{CV}=$ coefficient of variation $(* *=$ nyata pada taraf $1 \%(p<0.01), *=$ nyata pada taraf $5 \%(p<0.05)$, ns $=$ tidak nyata; $C V=$ koefisien keragaman $)$

Table 5. Agronomic characters of 12 soybean genotypes (Karakter agronomi 12 genotipe kedelai)

\begin{tabular}{clcccc}
\hline No & \multicolumn{1}{c}{ Genotype (Genotipe) } & DM & PH & FP & SW \\
\hline 1 & $11 \mathrm{AB}$ & 82 & 66.17 & 96.50 & 15.00 \\
2 & $13 \mathrm{ED}$ & 83 & 71.50 & 107.42 & 13.40 \\
3 & $14 \mathrm{DD}$ & 83 & 73.09 & 92.17 & 13.80 \\
4 & $19 \mathrm{BE}$ & 81 & 66.83 & 89.50 & 14.50 \\
5 & 25 EC & 81 & 72.58 & 91.75 & 12.90 \\
6 & G511H/Kaba//Kaba///Kaba-8-6 & 77 & 90.84 & 100.50 & 13.80 \\
7 & G511H/Anjs//Anjs-2-10 & 75 & 69.42 & 110.25 & 16.30 \\
8 & G511H/Anjs-1-3 & 77 & 56.17 & 85.50 & 15.00 \\
9 & G511H/Anj//Anj//Anj-11-2 & 75 & 74.25 & 101.50 & 14.90 \\
10 & G511H/Arg//Arg-2-1 & 76 & 63.08 & 76.67 & 16.80 \\
11 & Demas 1 & 85 & 67.50 & 113.08 & 11.10 \\
12 & Anjasmoro & 83 & 73.75 & 97.17 & 15.20 \\
\hline \multicolumn{2}{c}{ Average (Rata-rata) } & 80 & 70.43 & 96.83 & 2.37 \\
\hline
\end{tabular}

$\mathrm{DM}=$ days to maturity (day), $\mathrm{PH}=$ plant height $(\mathrm{cm}), \mathrm{FP}=$ number of filled pods/plant, $\mathrm{SW}=100$ seed weight $(\mathrm{g}), \mathrm{SY}=\mathrm{seed}$ yield $(\mathrm{t} / \mathrm{ha})$ $[D M=$ umur masak (hari), PH = tinggi tanaman (cm), FP = jumlah polong isi/tanaman, $S W=$ bobot 100 biji (g), SY $=$ hasil biji (t/ha)] 
variety) up to $87.23 \%$ (14DD) and it increase at $60{ }^{\circ} \mathrm{C}$. In this research, two soybean genotypes have been identified as resistant based on oven-dry method. The screening for resistance to pod shattering using oven-dry method have been done in several studies (Mohammed, 2010; Bhor et al., 2014; Kuai et al., 2016; Krisnawati and Adie, 2017a; Krisnawati and Adie, 2017b). A screening for shattering resistance in 150 soybean genotypes using oven-dry method by Krisnawati and Adie (2017a) obtained the pod shattering percentage ranged from $0 \%$ to $100 \%$.

Screening of resistance to pod shattering by drying the soybean straw (with the pods) under the sun, showed that the pod shattering after seven days of sun-drying have reached over $5 \%$. Furthermore, up to 15 days drying, it was obtained three resistant genotypes which two of them also classified as resistant based on the oven-dry method. The average of shattering at 15 days drying was $26.88 \%$, whereas the average of shattering at $60{ }^{\circ} \mathrm{C}$ (oven-dry method) was $51.06 \%$. Susceptible and moderately resistant genotypes based on the oven-dry method have become moderately resistant when it was based on the sundrying method. This indicates that oven-dry method puts more pressure on the occurrence of pod shattering, meanwhile the sun-drying method more reflects the real condition in the field. The advantages of screening using oven-dry method are provide controlled environment at a certain temperature, be able to screen soybean genotypes in large quantity and in a faster way, and are not affected by environment (e.g. cloudy or rain). The soybean yield losses due to pod shattering vary among soybean production centers. IITA (1986) reported yield losses between $50-100 \%$. Tiwari and Bhatnagar (1991) estimated that the yield losses due to pod shattering ranged from $34-99 \%$, depend on the duration of harvest delays, environment condition during the harvest period, and the susceptibility of the variety. In Japan, it was reported that the yield losses over $422 \mathrm{~kg} / \mathrm{ha}$ (Shirota et al., 2001).

A shattering resistant variety become the best option to reduce the yield losses due to pod shattering. In this study, the G511H/Anjs-1-3 was resistant to pod shattering based on the oven-dry as well as the sun-drying method. Various researches revealed that pod shattering resistance was controlled by genetic factor. Yamada et al. (2009) reported that soybean resistance to pod shattering was controlled by recessive gene. Furthermore, Agrawal et al. (2003) stated that segregation process of shattering trait was complex character on F2 generation, as quantitative response in the cross of susceptible and resistant varieties. Bhor et al. (2014) conducted a research on inheritance of pod shattering in soybean and obtained that soybean resistance to pod shattering was controlled by major genes with inhibitory epistasis were involved as evidenced from F2 ratio (13:3), and furthermore it was confirmed by test cross ratio $(3: 1)$ in resistance $\times$ susceptible and susceptible $\times$ resistance crosses. Zhang and Boahen (2010) studied the relationship between pod shattering and crop management, and obtained that non-irrigated soybean shattered faster than irrigated soybean. Based on those research was also reported that late maturing pods tended to have a more ability to hold seed better than the early maturing one.

Indonesia is one of soybean producing center in tropical regions, and the largest soybean cultivation is at the dry season. Optimization of soybean yield in tropical region is could be carried out by providing soybean resistant to pod shattering, as well as high yield and has suitable agronomic characters with tropical environment of Indonesia. Genotype G511H/Anjs-1-3 was identified as resistant to pod shattering and has identical resistance with Anjasmoro variety. It was able to produce $3.27 \mathrm{t} / \mathrm{ha}$, has early days to maturity (77 days), and large seed size based on seed-size classification in Indonesia. Thus, it could be developed on tropical area of Indonesia, and also suitable with industrial preference for soybean raw material.

\section{CONCLUSION}

The resistance to pod shattering vary among soybean genotypes. The use of oven-dry method resulted in a higher pressure than those of by sun-drying method on screening for shattering resistance. Soybean genotype G511H/Anjs-1-3 was 
identified as resistant to pod shattering, produce high yield, and have suitable agronomic characteristics to develop in the tropical region of Indonesia.

\section{ACKNOWLEDGMENT}

The authors gratefully thank the Indonesian Agency for Agricultural Research and Development (IAARD) for funding this research through the 2017 KP4S Program.

\section{REFERENCES}

Adeyeye, A.S., Togun, A.O., Akanbi, W.B., Adepoju, I.O. and Ibirinde, D.O., 2014. Pod shattering of different soybean varieties, Glycine max (L) Merrill, as affected by some growth and yield parameters. International Journal of Agricutural Policy and Research, 2(1), pp. 10-15.

Agrawal, A.P., Salimath, P.M. and Patil, S.A., 2003. Inheritance of pod shattering in soybean [Glycine $\max (\mathrm{L}$.) Merrill]. Indian Journal of Genetics and Plant Breeding, 63, pp. 265-266.

Agrawal, A.P., Basarkar, P.W., Salimath, P.M. and Patil, S.A., 2002. Role of cell wall-degrading enzymes in pod shattering process of soybean (Glycine max (L) Merrill). Current Science, 82(1).

Antwi-Boasiako, A., 2017. Screening of soybean (Glycine max (L.) Merrill) genotypes for resistance to lodging and pod shattering. International Journal of Agronomy and Agricultural Research, 10, pp.1-8.

Bara, N., Khare, D. and Srivastava, A.N., 2013. Studies on the factors affecting pod shattering in soybean Indian Journal of Genetics and Plant Breeding, 73(3), pp. $270-277$.

Bhor, T.J., Chimote, V.P. and Deshmukh, M.P., 2014 Inheritance of pod shattering in soybean [Glycine $\max$ (L.) Merrill]. Electronic Journal of Plant Breeding, 5, pp. 671-676.

Funatsuki, H., Hajika, M., Hagihara, S., Yamada, T., Tanaka, T., Tsuji, H., Ishimoto, M. and Fujino, K., 2008 Confirmation of the location and the effects of a major QTL controlling pod dehiscence, $\mathrm{qPDHI}$, in soybean. Breeding Science, 58, pp.63-69.

Gulluoglu, L., Halis, A. and Mehmet, A., 2006. Effects of some plant growth regulators and nutrient complexes on pod shattering and yield losses of soybean under hot and dry conditions. Asian Journal of Plant Sciences, 5, pp. 368-372.

IITA [International Institute of Tropical Agriculture], 1986. A laboratory method for evaluating resistance to pod shattering in soybeans. Annual Report 58-59. IITA. Ibadan, Nigeria.
Krisnawati, A. and Adie, M. M., 2017a. Identification of soybean genotypes for pod shattering resistance associated with agronomical and morphological characters. Biosaintifika: Journal of Biology \& Biology Education, 9(2), pp. 26-32.

Krisnawati, A. and Adie, M.M., 2017b. Variability on morphological characters associated with pod shattering. Biodiversitas, 18, pp.73-77.

Kuai, J., Sun, Y., Liu, T., Zhang, P.I., Zhou, M., Wu, J. and Zhou, G., 2016. Physiological mechanisms behind differences in pod shattering resistance in Rapeseed (Brassica napus L.) varieties. PLOS ONE, 1-12. doi:10.1371/journal.pone.0157341.

Liu, J., Wang, J., Wang, H., Wang, W., Zhou, R., Mei, D., Cheng, H., Yang, J., Raman, H. and Hu, Q., 2016. Multigenic control of pod shattering resistance in Chinese Rapeseed germplasm revealed by genome-wide association and linkage. Frontiers in Plant Science, 7, pp. 1-14.

Mohammed, H., 2010. Genetic analysis of resistance to pod shattering in soybean (Glycine max. (L) Merrill) [Thesis]. The Department of Crop and Soil Sciences, Faculty of Agriculture of the College of Agriculture and Natural Resources, Kwame Nkrumah University of Science and Technology, Kumasi.

Morgan, C.L., Bruce, D.M., Child, R., Ladbrooke, Z.L. and Arthur, A.E., 1998. Genetic variation for pod shatters resistance among lines of oilseed rape developed from synthetic Brassica napus. Field Crops Research, 58, pp. 153-165.

Tukamuhabwa, P., Rubaihayo, P.R., Dashiell, K. and Adipala, E., 2000. Inheritance of resistance to pod shattering in soybean. African Journal of Crop Science, 8, pp. 203-212.

Shirota, M., Hamada, Y., Nakajima, Y., Tani, T., Yoshida, T., Shaku, I. and Uchida, T., 2001. Study on actual condition of pre-harvest shatter loss on soybean caltivation in Aichi Prefecture. Japan Journal of Crop Science, 70(2), pp. 23-24.

Tiwari, S. and Bhatnagar, P., 1989. Minimizing pod shattering in soybean. Indian Farming, 39, pp. 23-24.

Thompson, K. F. and Hughes, W. G., 1986. Breeding and varieties. In: Scarisbrick, D. H. and Daniels, R.W. eds. Oilseed Rape. Collins. London.

Tiwari, S.P. and Bhatnagar, P.S., 1991. Pod shattering as related to other agronomic attributes in soybean. Tropical Agriculture, 68, pp.102-103.

Tukamuhabwa, P., Dashiell, K.E., Rubaihayo, P. and Nabasirye M., 2002. Determination of field yield loss and effect of environment on pod shattering in soybean. African Crop Science Journal, 10, pp. 203-209.

Yamada, T., Funatsuki, H., Hagihara, S., Fujita, S., Tanaka, Y., Tsuji, H., Ishimoto, M., Fujino, K. and Hajika, M. 2009. A major QTL, $q P D H 1$, is commonly involved in shattering resistance of soybean cultivars Breeding Science, 59, pp. 435-440.

Zhang, L. and Boahen, L., 2010. Evaluation of critical shattering time of early maturity soybeans under early soybean production system. The Agriculture and Biology Journal of North America, 1(4), pp. 440-447. 